\title{
Design of a Self-esteem Scale for Schoolchildren: EVA 2015*
}

\section{Diseño de una Escala de Evaluación de la Autoestima: EVA 2015}

\author{
Miren De Tejada Lagonell ${ }^{\mathrm{a}}$ \\ Universidad Pedagógica Experimental Libertador, \\ Venezuela \\ ORCID: http://orcid.org/0000-0003-1854-3997 \\ FRANCESC SidERA \\ Universitat de Girona, España \\ ORCID: http://orcid.org/0000-0001-7107-0450 \\ Maria Eugènia Gras \\ Universitat de Girona, España \\ ORCID: http://orcid.org/0000-0003-4765-0871 \\ Delia Mera \\ Instituto Pedagógico de Caracas, Venezuela \\ ORCID: http://orcid.org/0000-0001-6297-0027
}

\begin{tabular}{ll}
\hline a Correspondence & author.
\end{tabular}

Para citar este artículo: De Tejada Lagonell, M., Sidera, F., Gras, M, E., \& Mera, D. (2018). Design of a Self-esteem Scale for Schoolchildren: EVA 2015. Universitas Psychologica, 17(4), 1-11. https://doi.org/ 10.11144/Javeriana.upsy17-4.dsss

\begin{abstract}
Background. We designed and validated a Self-Esteem Scale for Catalan and Venezuelan schoolchildren, with the joint aims of both examining its psychometric properties and emergent factors, and comparing its behaviour between the two communities. Method. Data collection was conducted twice: a pilot (300 schoolchildren) and a final test (636 schoolchildren aged from 6 to 9 years). Results. A factor analysis (principal component analysis) of the Catalan sample conformed a final instrument with 19 items organized into 4 factors: Social acceptance, Negative emotions, School satisfaction, and Self-assessment. A confirmatory factor analysis was conducted on the Venezuelan sample, and the method of maximum likelihood estimation suggested a good fit $(\mathrm{CFI}=0.94 ;$ RMSEA $=0.039)$. Conclusions. The factors emerging from the scale suggest different dimensions of self-esteem at the beginning of school age.
\end{abstract}

Keywords

Self-Esteem; School Age; Culture; Scale; Evaluation.

\section{RESUMEN}

Antecedentes. En esta investigación se diseñó y validó una Escala de Autoestima para escolares catalanes y venezolanos, con el fin de examinar sus propiedades psicométricas, los factores que emergen y comparar su comportamiento entre ambas comunidades. Método. Se realizaron dos recogidas de datos: prueba piloto (300 escolares) y prueba final (636 escolares). Los participantes de la prueba final tenían entre 6 y 9 años de edad, todos alumnos de primero a tercero de primaria. Resultados. A partir de un análisis factorial (análisis de componentes principales), con la muestra catalana, el instrumento quedó conformado por 19 ítems organizados en cuatro factores: Aceptación social, Emociones negativas, Satisfacción escolar y Autovaloración. Se llevó a cabo un análisis factorial 
confirmatorio con la muestra venezolana, donde el método de estimación de máxima verosimilitud sugirió un buen ajuste $(\mathrm{CFI}=0.94$; RMSEA $=0.039)$. Conclusiones. Los factores que emergen en la escala indican una diferencialidad de las dimensiones de la autoestima al inicio de la edad escolar, en dos culturas distintas con lenguajes también distintos.

Palabras clave

autoestima; edad escolar; cultura; escala; evaluación.

Self-esteem has previously been associated with other variables in research addressing issues such as the following, among others: academic performance (Serrano, Mérida, \& Tabernero, 2016); emotional intelligence (Rodríguez, 2012); school success and socioeconomic level (Muñoz, 2011); perceptions of stress and coping (Verduzco, Gómez, \& Duran, 2004); support classes for students at high social risk (Ramírez, Duarte, \& Muñoz, 2005); socioeconomic status (Twenge \& Campbell, 2002); and reading skills (De Tejada, 2009), among others.

Many studies highlight the importance of selfesteem as a catalyst for the learning process in the context of education (Villarroel, 2001) and as a key component in the construction of the self in schoolchildren; this being understood as a system consisting of three elements: a) our self-concept or view of what we are; b) our self-control or awareness of our own skills and abilities to determine and guide our behaviour; and c) selfesteem or acknowledgement of the feelings we have about ourselves (León, 2007). Hence the importance of developing tools for assessing selfesteem in children of school age. In this sense, the aim of this research was to develop a self-esteem scale for Catalan and Venezuelan schoolchildren and evaluate its psychometric properties. In this study, self-esteem is conceptualised as the set of experiences and feelings that children share with significant people in their social and emotional environment and their views of their own skills and abilities (Alonso \& Román, 2005; De Tejada, 2009).

The interest in developing a single scale for both communities lies in the fact that they belong to different cultures, so the creation of evaluation tools suitable for both would allow for a better understanding of these communities. On the other hand, several authors have pointed out the importance of evaluating self-esteem as an indicator for monitoring the psychological health of children (Navarro, Meléndez, Sales, \& Sancerni, 2012; Serrano et al., 2016). Likewise, these authors also note that in the mental health evaluation protocols for children from 3 to 18 years of age, tools for evaluating selfesteem should be included, as they allow for the development of early intervention programs for school-age children.

In designing the scale described in the present article, which we have named EVA 2015 (standing for "Escala de Evaluación de la Autoestima", or Scale for Evaluating Self-esteem), we have followed a series of principles that the scales for measuring selfesteem, self-concept, or self-image in children and adolescents usually follow (Butler \& Gasson, 2005): a) They are self-administered instruments; b) They focus on a subjective evaluation of the self; c) They assume that the self is quantifiable and deducible from salient attributes of the individual's personality; d) They assume self-esteem as the product of a personal construction, meaning it is inevitable that there will be variability in how individuals perceive themselves.

It has been noted that tests used to assess self-esteem are mostly adaptations of traditional instruments, such as those proposed by Rosenberg (1965) or Coopersmith (1981), or the Piers-Harris Self-Concept Scale (Piers, 1969, 1984), and generally hailing from the United States (Butler \& Gasson, 2005). The scale described in the present study is constructed in both Catalan and Spanish, after the revision of the abovementioned traditional scales, but also considering other scales such as Edina (Mérida, Serrano \& Tabernero, 2015), EVA 2010 (De Tejada, 2015), and IDAI (Giménez, Cortés, \& Loaeza, 2003).

Some of the conceptual aspects considered in the design of the scale are as follows: a) Schmitt and Allik (2005) found empirical evidence in favour of a universal theoretical position on self-esteem, understanding it as a 
universal phenomenon originating from common human motivations; b) Brinthaupt and Erwin (1992) stated that self-esteem includes: measures for assessing the self, one's level of satisfaction with or acceptance of an aspect of the self, and aspects involving an assessment of the discrepancy between the actual self and the ideal self; c) Butler and Gasson (2005) found that the most commonly cited selfconcept scales contain no information on their theoretical stance, although most follow a multidimensional and hierarchical theoretical structure and contain items generated by the authors themselves; d) Caso, HernándezGuzmán, and González-Montesinos (2011) highlight that the conceptualisation of selfesteem depends on the developmental stage and on the contexts in which people interact; and e) According to Palacios (2000), the term selfesteem has been considered to encompass a set of relatively independent dimensions (physical, academic, emotional, and school-related, among others), and this set of dimensions becomes increasingly complex and multidimensional with age

Some methodological aspects that have been considered in the design of the present scale are as follows: a) as age increases, the content of children's self-reported questionnnaires changes from specific, physical, and behavioural characteristics to more abstract general characteristics (Butler \& Gasson, 2005); b) some authors have suggested that children have trouble answering items worded negatively (Benson \& Hocevar, 1985; Marsh, 1986). Schmitt and Allik (2005) found that when some items are worded negatively, the responses of some children, especially younger ones, are the opposite of their actual intentions; c) Brinthaupt and Erwin (1992) found that in their descriptions of themselves, children rarely used sentences with a negative tone; d) Davis-Kean and Sandler (2001), in a meta-analysis of measures of selfesteem for young children, found that those that used questionnaires (only questions with two responses or Likert-style responses) were more reliable than those that used drawings or other tools as aids. Furthermore, administering the tests in a school setting predicted greater reliability.

Finally, it is worth noting that few studies have directly investigated self-esteem in young children by means of scales or tests (see, for example, Butler \& Gasson, 2005), which expresses the need to accomplish the objective of the present study, which is to generate a SelfEsteem Assessment Scale applicable to Catalan and Spanish-speaking children, according to the theoretical and methodological aspects described just above.

\section{Method}

\section{Participants}

In order to achieve our stated objective, data collection was conducted twice. A pilot test was carried out to enable the final selection of items, followed by a final test. The population of the pilot test comprised 300 participants, 203 from Catalonia and 97 from Venezuela, attending years one to three of primary school. The age range was 5.92 to 10.08 years $(M=7.98 ; S D=$ 0.90).

To obtain the sample for the final test, we proceeded as follows. In Catalonia, a list of state schools was compiled from the province of Girona (including 6 counties of the province, and excluding 3 , for reasons of geographical proximity) and five schools were randomly selected. For the Venezuela sample, the selection was based on non-probabilistic purposive sampling. In both cases, we received consent from the schools' governing bodies. The test was not administered to some children for one of the following reasons: a) they would not understand, in the teacher's opinion, the language in which the test was administered; b) they did not receive parental consent; c) they did not attend school on the day of the test.

The final test sample consisted of 636 schoolchildren aged 6 to 9 years old (range: 6 to 9.83 years; $M=7.89, S D=0.90$ ). Table 1 provides data for the age of participants by school year, gender, and country. Participants were from 
Venezuela (267) and Catalonia (369), where they attended years one to three of Basic Education (Venezuela) or primary school (Catalonia).

Table 1

Age of participants at the final test (in years) by gender, school year and country

\begin{tabular}{|c|c|c|c|c|c|c|}
\hline \multirow{2}{*}{ Country } & \multirow{2}{*}{ Grade } & \multirow{2}{*}{ Gender } & \multirow{2}{*}{$\mathrm{N}$} & Minimum & Maximum & Mean \\
\hline & & & & Age & Age & Age (SD) \\
\hline \multirow{6}{*}{ Catalonia } & 1 & boys & 66 & 6.33 & 7.92 & $6.90(0.29)$ \\
\hline & & girls & 63 & 6.42 & 7.33 & $6.93(0.30)$ \\
\hline & \multirow[t]{2}{*}{2} & boys & 68 & 7.33 & 8.42 & $7.91(0.30)$ \\
\hline & & girls & 65 & 7.42 & 8.83 & $7.90(0.31)$ \\
\hline & \multirow[t]{2}{*}{3} & boys & 52 & 8.33 & 9.83 & $8.87(0.32)$ \\
\hline & & girls & 55 & 8.42 & 9.33 & $8.91(0.27)$ \\
\hline \multirow{6}{*}{ Venezuela } & \multirow[t]{2}{*}{1} & boys & 46 & 6.00 & 8.25 & $7.01(0.41)$ \\
\hline & & girls & 64 & 6.33 & 7.50 & $6.94(0.29)$ \\
\hline & \multirow[t]{2}{*}{2} & boys & 40 & 7.50 & 9.25 & $8.11(0.49)$ \\
\hline & & girls & 37 & 7.50 & 9.83 & $8.17(0.53)$ \\
\hline & \multirow[t]{2}{*}{3} & boys & 40 & 8.50 & 9.83 & $9.15(0.34)$ \\
\hline & & girls & 40 & 8.42 & 9.83 & $9.05(0.33)$ \\
\hline
\end{tabular}

\section{Instruments}

The self-reported test used was designed specifically for this research. It consisted of a group administration Likert scale, comprising 53 items for the pilot test and 32 for the final test. The items consisted of positively-worded statements and referred to positive aspects of children's lives, with the exception of some items related to emotions.

For each item, participants had to mark the most appropriate response with a cross. There were 3 possible answers, based on the frequency with which the child felt in the way described: "always," "sometimes," or "never". Each item had a value of $0-2$ points. In some items, the response "always" received 2 points and "never" 0 points, while in others it was the reverse $(0$ points for "always" and 2 points for "never"). "Sometimes" always scored one point. Thus, the possible range of scores for the final test was 0 to 64 points.

The following tests were reviewed for the wording of items: the self-esteem assessment scale (De Tejada, 2009), the self-description questionnaire (Marsh, 1988), the self-perception profile for children (Harter, 1985), the pictorial scale of perceived competence and social acceptance for young children (Harter \& Pike, 1984), the self-esteem inventory (Coopersmith, 1981), the Piers-
Harris children's self-concept scale, 2 nd edition (Piers, Harris, \& Herzberg, 2002), and finally, the multimedia and multilingual self-esteem assessment questionnaire (Ramos \& Santamaría, 2010). Three of the four authors of the present study wrote the items of the pilot study by grouping the items of these tests according to their content (grouping the items with similar content). These items were in turn classified into 7 dimensions.

The 53 items included in the pilot test were initially written in Spanish and then translated into Catalan. Once the pilot had been administered, a principal component analysis was carried out with 7 fixed factors, for both the Catalan and Venezuelan samples. On the basis of these analyses, items were chosen for the final test which weighed a score superior to 0.3 on the same factor. In the pilot sample, the KaiserMeyer-Olkin measure of sampling adequacy was 0.734 in Catalonia and 0.493 in Venezuela, and Bartlett's test of sphericity was statistically significant in both samples (Catalonia: $x^{2}=$ 3295.21, $p<0.001$; Venezuela: $x^{2}=1827.32, p$ $<0.001)$.

Thus, a total of 32 items were selected to comprise the final test. The following factors were found: a) social acceptance (10 items); b) negative emotions (7 items); c) physical selfassessment (3 items); d) school satisfaction (3 items); e) family relationships (3 items); f) ability to learn (3 items); g) physical activity and sport (3 items). Apart from these 32 items, 2 example items not included in the final test analysis were also included in order for participants to understand how to respond to the scale.

\section{Procedure}

School heads were contacted prior to administering the pilot and final tests to explain the aims of the study.

Both tests were administered to the students as a group. The items were read aloud by the test adminstrator, who checked the children were paying attention and marking their responses in the appropriate row. 
The instructions given to participants were as follows: "We're going to do a different activity to the ones you normally do in the classroom. We're going to read out some questions about how you feel". The questionnaires were then handed out and participants were asked to use a pencil to mark their answer. They were first asked to fill in the personal data section of the questionnaire, and then told, "We're going to read a few sentences about how we feel sometimes, always, or never, in relation to the activities we do with our parents, teachers, and friends. As we read, mark one of the three options in the column: I always feel like this, I sometimes feel like this, or I never feel like this, according to how you feel about the sentence. Think carefully before you answer".

Exploratory factor analysis was used in the Catalan sample to explore the factorial structure of the Self Esteem Scale, and then this model was fitted in the Venezuelan sample using Confirmatory factor analysis.

Version 19 of the SPSS statistics package was used for the principal component factor analysis and version 18.0 of the AMOS program for the confirmatory factor analysis. A total of 63 responses had missing values from a total of 46 participants. Thus, 590 participants responded to all questions correctly. In the factor analysis, missing values were replaced by the mean of the item.

The goodness of fit indices used included the Satorra-Bentler index and the Non-Normed Fit Index (NNFI) and Comparative Fit Index (CFI). NNFI and CFI values around 0.90 are acceptable. The Standarized Root Mean Squared (SMRM) and the Root-Mean Squared Error of Aprroximation Measures Residuals (RMSEA) were also used. SMRM and RMSEA values lower than 0.05 are acceptable.

\section{Results}

\section{Internal structure of the scale}

First, the psychometric properties of the scale of 32 items in the Catalan sample $(\mathrm{n}=369)$ were analysed by means of exploratory factor analysis with varimax rotation. The KaiserMeyer-Olkin measure of sampling adequacy was 0.851 and Bartlett's sphericity test was statistically significant $\left(x^{2}=3150.01 ; p<\right.$ 0.001 ), indicating that it was appropriate for the factor analysis. The scree plot suggested an initial solution of 5 factors. Only those items loading more than 0.4 on a certain factor and less than 0.3 on the rest were retained (see Table 2). Following this criterion, items 3, 6, 10, 13, 16, 22, $24,25,28,30$ and 31 were removed.

\section{Table 2}

Factor loadings of the 32-item 5-factor scale

\begin{tabular}{|c|c|c|c|c|c|}
\hline Item description & $\begin{array}{c}\text { Factor } \\
1\end{array}$ & $\begin{array}{l}\text { Factor } \\
2\end{array}$ & $\begin{array}{l}\text { Factor } \\
3\end{array}$ & $\begin{array}{c}\text { Factor } \\
4\end{array}$ & $\begin{array}{l}\text { Factor } \\
5\end{array}$ \\
\hline I like my parents (1) & -0.01 & -0 & 0.11 & 0.51 & -0.08 \\
\hline My friends come to play when I invite them (2) & 0.52 & -0.15 & 0.26 & 0.08 & -0.05 \\
\hline I am scared (3) & 0.03 & -0.07 & 0.43 & -0 & 0.49 \\
\hline I like my face (4) & 0.16 & 0.08 & -0.04 & 0.68 & 0.26 \\
\hline I feel good at school (5) & 0.17 & 0.59 & 0.26 & 0.22 & -0.11 \\
\hline I learn easily what my teacher teaches me (6) & 0.33 & 0.42 & 0.13 & -0.26 & 0.19 \\
\hline $\begin{array}{l}\text { I have energy to play as much as I want: to } \\
\text { jump, to run... (7) }\end{array}$ & 0.2 & 0.01 & 0.06 & 0.14 & 0 . \\
\hline Other children let me play with them (8) & 0.63 & -0.04 & 0.14 & -0.06 & 0.17 \\
\hline I am bored (9) & 0.06 & 0.25 & 0.40 & 0.17 & 0.08 \\
\hline I like my body ( 1 & 0.16 & 0.15 & -0.06 & 0.57 & 0.35 \\
\hline omewok (11) & 0.05 & 0.75 & -0.01 & 13 & 0.06 \\
\hline My parents value me (12) & 0.17 & -0.07 & 0.18 & 0.45 & -0.26 \\
\hline I learn easily new gam & 0.07 & 0.28 & 0.18 & -0.01 & 0.36 \\
\hline I like to run (14) & 0.19 & 0.09 & -0.08 & 0.04 & 0.56 \\
\hline Other children want to be my friends ( 15 ) & 0.64 & 0.12 & 0.08 & 0.14 & 0.13 \\
\hline I am afraid (16) & -0.05 & -0.01 & 0.44 & -0.04 & 0.56 \\
\hline My classmates want to & 0.65 & 0.18 & 0.16 & 0.12 & 0.05 \\
\hline I think I'm good lool & 0.2 & 0.15 & -0.11 & 0.64 & 0.06 \\
\hline at school (19) & 0.14 & 0.78 & 0.10 & 0.13 & -0.02 \\
\hline I make friends easily (20) & 0.55 & 0.07 & 0.08 & 0.11 & 0.17 \\
\hline My friends like me & 0.69 & 0.24 & 0.006 & 0.16 & 0.08 \\
\hline I lern easily what they teach me at school (22) & 0.34 & 0.48 & 0.12 & -0.13 & 0.29 \\
\hline I'm lonely (23) & 0.26 & -0.01 & 0.62 & 0.05 & 0.09 \\
\hline tell me & 0.46 & 0.31 & -0.14 & 0.31 & 0.13 \\
\hline my fam & 0.17 & 0.12 & 0.12 & 0.24 & -0.24 \\
\hline I'm ner & 0.06 & 0.09 & 0.61 & -0.02 & -0.04 \\
\hline vell (27) & 0.63 & 0.2 & 0.22 & 0.17 & -0.09 \\
\hline Other people like me (28) & 0.57 & 0.33 & -0.03 & 0.36 & 0.02 \\
\hline $\mathrm{I}$ 'm s & 0.15 & 0.07 & 0.60 & -0.09 & 0.26 \\
\hline I feel gc & 0.22 & 0.28 & 0.20 & 0.04 & 0.23 \\
\hline My classmates think & 0.58 & 0.44 & 0.03 & 0.02 & 0.04 \\
\hline I'm angry (32) & 0.10 & 0.16 & 0.70 & 0.04 & -0.03 \\
\hline
\end{tabular}

Note: Items loading more than 0.3 appear in bold.

Only factors with over 0.5 internal consistency were retained for the analysis, leading to the elimination of the fifth factor (alpha $=0.44$ ), which included items 7 and 14, and the analysis was repeated using the remaining 19 items and four factors. This new analysis revealed that item 9 did not reach a loading value of 0.4 on any of the factors and had a factor loading greater than 0.3 on factors 2 and 3, leading to the item being removed and the analysis being repeated with the remaining 18 items and 4 factors. All items met the criteria with this analysis. The psychometric properties of the selected items are presented in Table 3. The seven items that loaded on the first factor are related to social acceptance 
by friends. The four items that loaded on the second factor express negative emotions. The three items that loaded on the third factor refer to school satisfaction, and finally, the four items that loaded on the fourth factor were related to self-assessment. The variance explained by the four factors was $50.55 \%$.

\section{Table 3}

Description, descriptive indices, and factor loadings of the items and Cronbach's alpha, eigenvalues, and explained variance for rotated factors for each factor

\begin{tabular}{|c|c|c|c|c|c|c|c|}
\hline Item Description & Mean & SD & $\begin{array}{c}\text { Factor } \\
\text { load }\end{array}$ & Eigenvalue & $\begin{array}{c}\text { Explained } \\
\text { variance }\end{array}$ & $\alpha^{*}$ & $\alpha$ \\
\hline Factor 1. Social acceptance & & & & 4.42 & $17.54 \%$ & & 0.8 \\
\hline $\begin{array}{l}\text { Other children want to be my } \\
\text { friends (15) }\end{array}$ & 1.6 & 0.57 & 0.74 & & & 0.76 & \\
\hline $\begin{array}{l}\text { Other children let me play with } \\
\text { them }(8)\end{array}$ & 1.5 & 0.6 & 0.71 & & & 0.77 & \\
\hline My friends like me as I am (21) & 1.55 & 0.58 & 0.68 & & & 0.76 & \\
\hline $\begin{array}{l}\text { My classmates want to sit next to } \\
\text { me (17) }\end{array}$ & 1.45 & 0.59 & 0.67 & & & 0.75 & \\
\hline My classmates treat me well (27) & 1.5 & 0.59 & 0.62 & & & 0.76 & \\
\hline I make friends easily (20) & 1.58 & 0.58 & 0.56 & & & 0.78 & \\
\hline $\begin{array}{l}\text { My friends come to play when I } \\
\text { invite them (2) }\end{array}$ & 1.43 & 0.62 & 0.5 & & & 0.8 & \\
\hline Factor 2. Negative emotions & & & & 1.88 & $12.09 \%$ & & 0.69 \\
\hline$I ' m$ angry (32) & 1.36 & 0.59 & 0.76 & & & 0.6 & \\
\hline I'm sad & 1.41 & 0.58 & 0.7 & & & 0.61 & \\
\hline I'm & 1.49 & 0.68 & 0.68 & & & 0.61 & \\
\hline I'm nervous (26) & 1.23 & 0.63 & 0.64 & & & 0.67 & \\
\hline Factor 3. School s & & & & 1.51 & $11.34 \%$ & & 0.72 \\
\hline $\begin{array}{l}\text { I'm happy with the work I do at } \\
\text { school (19) }\end{array}$ & 1.68 & 0.56 & 0.83 & & & 0.56 & \\
\hline I enjoy doing homework (11) & 1.52 & 0.66 & 0.82 & & & 0.62 & \\
\hline I feel good at school (5) & 1.67 & 0.52 & 0.62 & & & 0.71 & \\
\hline Factor 4. Self-assessment & & & & 1.29 & $9.56 \%$ & & 0.52 \\
\hline I like & 1.93 & 0.27 & 0. & & & 0.51 & \\
\hline & & 0.4 & 0. & & & & \\
\hline My & & 0 & & & & 0.51 & \\
\hline I think I'm good-looking (18) & 1.71 & 0.58 & 0.55 & & & 0.39 & \\
\hline
\end{tabular}

*Cronbach's alpha if item is removed

\section{Confirmatory factor analysis}

In order to test the goodness of fit of the factor solution for the four factors identified in the Catalan sample by means of explotatory factor analysis, we conducted a confirmatory factor analysis on the sample of Venezuelan students $(n=267)$. Version 18.0.0 of the AMOS software was used and the adjustment was made using the method of maximum likelihood estimation. Missing data were processed using the EM (Expectation Maximization Method). The goodness of fit indices used were the Satorra-Bentler index and the NNFI (Nonnormed Fit Index) because data did not follow normality. The SMRM (Standardized Root Mean Squared) and RMSEA (Root-Mean Square Error of Approximation Measures Residuals) were also used. The results show that the fit is good $\left(x^{2}\right.$
$=253.8, \mathrm{p}<0.001 ; \mathrm{NNFI}=0.89 ; \mathrm{CFI}=$ 0.94; $\mathrm{SRMR}=0.043$, RMSEA $=0.039,95 \%$ CI $(0.032: 0.046))$. Table 4 shows the standarized factor loadings of the scale EVA 2015. The Cronbach's alpha values were as follows: social acceptance 0.81 (7 items); negative emotions 0.61 (4 items); school satisfaction 0.61 ( 3 items); and self-assessment 0.47 (4 items).

\section{Table 4}

Factor loadings EVA 2015

\begin{tabular}{lr}
\hline \multicolumn{1}{c}{ Items } & $\begin{array}{r}\text { Factor } \\
\text { loading }\end{array}$ \\
\hline \multicolumn{2}{c}{ Factor 1. Social Aceptance } \\
Other children want to be my friends (15) & 0.64 \\
Other children let me play with them (8) & 0.62 \\
My friends like me as I am (21) & 0.65 \\
My classmates want to sit next to me (17) & 0.68 \\
My classmates treat me well (27) & 0.61 \\
I make friends easily (20) & 0.52 \\
My friends come to play when I invite them (2) & 0.5 \\
$\quad$ Factor 2. Negative emotions & \\
I'm angry (32) & 0.59 \\
I'm sad (29) Factor 3. School satisfaction & 0.61 \\
I'm lonely (23) & 0.57 \\
I'm nervous (26) & 0.49 \\
I'm happy with the work I do at school (19) & 0.73 \\
I enjoy doing homework (11) & 0.67 \\
I feel good at school (5) & 0.53 \\
\multicolumn{2}{c}{ Factor 4. Self-assessment } \\
I like my parents (1) \\
I like my face (4) \\
My parents value me (12) \\
I think I'm good-looking (18) \\
\hline$\quad 0.26$ \\
$\quad 0.6$ \\
$\quad 0.55$ \\
\hline
\end{tabular}

\section{Discussion}

In the present study, we analysed a scale aimed at evaluating self-esteem among Catalan and Venezuelan schoolchildren, which we have named EVA 2015. The scale is composed of 19 items grouped into four factors (social acceptance, negative emotions, school satisfaction, and self-assessment), and has (mostly) reliability and validity indices which are generally acceptable for research in the field of social sciences according to the criteria posited by Hair, Anderson, Tathan, and Black (2005).

The Cronbach's $\alpha$ of EVA 2015's internal consistency reliability coefficient ranged from 0.52 to 0.80 for the Catalan sample, and from 0.47 to 0.81 for the Venezuelan sample. It should 
be noted, however, that the self-assessment factor displayed a low Cronbach's $\alpha$, and it should therefore be retested or reconsidered in future research. Moreover, the variance explained by the scale was $50.55 \%$, so there is still an important part of the self-esteem construct that is not explained by our scale.

Another important aspect worth taking into account here is Butler and Gasson's (2005) observation that scales for measuring self-esteem embrace a set of principles (see introduction). We have retained these for our scale, in that it is a self-administered instrument whose items act as triggers for a reflective process that invites children to search for inner responses to express how they feel at a given time.

As far as a comparison with traditional tests for evaluating self-esteem is concerned, such as those proposed by Rosenberg (1965), PierreHarris (1969), and Coopersmith (1981), EVA 2015 is also self-administered; it has fewer items than the Pierre-Harris (1969) and Coopersmith (1981) scales, which contain approximately 80, and is closer to that of Rosenberg (1965), which has 10 items. However, all of the items included in EVA 2015 support the construct, unlike Rosenberg's traditional test, whose items are divided equally between those which are positively and negatively worded. The latter aspect has been reported to possibly hinder the assessment of self-esteem among smaller children due to the difficulty they might have in understanding the items (Benson \& Hocevar, 1985; Marsh, 1986). Additionally, in Rosenberg (1965) only one factor is reported; in PierreHarris (1969) a factor analysis with 10 emergent factors is reported; other studies have identified 6 confirmed factors; while Coopersmith (1981) reported nine emergent factors, and other cases have found 4 or 5 factors (see, for example, Butler $\&$ Gasson, 2005). In EVA 2015, four factors are reported with items favourable to the construct of self-esteem.

With regard to other tests assessing selfesteem, EVA 2015 might correspond, in some factors and item contents, to the EVA 2010 Self-Esteem Assessment Scale, designed and constructed for Venezuelan schoolchildren in the northeast sector of Greater Caracas (De Tejada, 2015). On the latter scale, school satisfaction also was found to be the third most important factor, thus confirming that the school environment is an important setting for generating self-esteem in schoolchildren. General dissatisfaction appears as the first factor; the items of which are negatively related to the self-esteem construct and include a set of feelings associated with negative emotions, as is the case with the second factor on EVA 2015. Finally, the fifth factor, selfacceptance (EVA 2010), may correspond to the fourth factor on EVA 2015, self-assessment.

Then there is the IDAI scale (Giménez et al., 2003), which was designed to assess selfesteem among Mexican schoolchildren aged between 8 and 12 and obtained a Cronbach's $\alpha$ of 0.91 . This test identified and validated four factors for assessing self-esteem: family acceptance (0.71), academic competence (0.77), personal safety (0.7), and popularity (0.71). These factors would correspond to some of the factors identified in EVA 2015. Thus, the popularity factor contains items that correspond to the first factor of social acceptance; academic competence is made up of items that correspond to the third factor, school satisfaction. The items included in family acceptance would relate to the fourth factor of self-assessment, and personal safety includes items that embody negative emotions (dissatisfaction, fear, anxiety), which would relate in content to the second factor on EVA 2015, negative emotions. In this regard, it is worth highlighting that the items on the EVA 2015 test essentially retain the same scenarios of interest (family, school, friends) as the IDAI (2003) with regard to the generation of selfesteem in children.

Furthermore, in Spain we find the EDINA Questionnaire (Mérida et al., 2015), which was applied to a sample of 241 children aged between 3 and 7 attending pre-primary and primary school. Its application obtained a Cronbach's $\alpha$ of 0.70 and 18 items were organized into a theoretical structure with four components: physical, academic, social emotional, and family. They show adequate reliability in terms of internal consistency, both by individual factor 
and for the whole questionnaire. Similarly to the IDAI and EVA 2010 questionnaires, EDINA has a factorial structure whose items are organized into dimensions that may also correspond to those included on EVA 2015. Thus, we find that the fourth factor, self-assessment, may correspond to the fourth factor on EDINA, family dimension, following the same hierarchical structure in both tests. The third factor on EVA 2015, school satisfaction, contains items that would in essence correspond to the second factor on EDINA, related to the academic dimensio;. while the second factor on EVA 2015, negative emotions, also contains items that would correspond to the third factor on EDINA, social emotional.

Some of the limitations that might be considered in our research refer to the following aspects: a) The participants of both samples are comparable in terms of age, but we do not know if they are comparable in other terms (e.g., IQ, linguistic level, ...); b) for the creation of our scale we did not review all the scales or tests that exist; c) the scale we propose herec can be used in Catalan and Spanish, but we did not prove that their factorial structure is equivalent; d) when we translated the scale from Spanish to Catalan, we did not meet all the guidelines that have been suggested (see, for example, Muñiz, Elosua, \& Hambleton, 2013); d) regarding the reliablility of the instrument, we only evaluated its internal consistency, whereas other strategies could have been used; e) in terms of validity, we just evaluated the internal structure of the instrument, but no evidences based on content were given

Despite the abovementioned limitations, the self-esteem scale elaborated in this paper has some positive aspects. First, in comparison to other instruments, in our scale the items are described only in positive sentences, which makes it easier for children as young as 6 years of age to understand. Secondly, it is an instrument designed for children from different cultures and with different languages, which should allow for a cross-cultural comparison of children's self-esteem and development. Third, it is an instrument with just 19 items, which might help to avoid fatigue effects in young children. Finally, it was designed after a revision of several instruments for evaluating self-esteem, so it represents an elaboration of items based on those aspects of self-esteem that previous studies have deemed as relevant.

By way of conclusion, it is worth noting some of the contributions made by EVA 2015. First, the limited number of items (19) on the scale allows self-esteem in children to be assessed rapidly. It also covers an age range (6-9 years old) that is outside the one of some other selfesteem assessment tests in schoolchildren, while still retaining good reliability, which seems to be problematic for younger ages (see Davis-Kean \& Sandler, 2001). And finally, it is worth noting that the factors included in the test suggest the existence of different dimensions of selfesteem at the beginning of school age, including social acceptance by friends, satisfaction with school, negative emotions, self-assessment, and assessment of parents; dimensions that have been identified in two different cultures with different languages. In this respect, it would be interesting to investigate whether these dimensions would be the same in populations with other cultures and languages.

\section{Acknowledgements}

We thank all the children who participated in this study. We are also very grateful to the following schools, for their help in the data collection: from Catalonia, escola Castanyer de Sant Joan les Fonts, escola Parc de les Aigües de Figueres, escola Puig de les Cadiretes de Llagostera, escola Joana d'Empúries de Castelló d'Empúries and escola Carles Faust de Blanes; form Venezuela, escuela Gustavo Ledo and escuela Mariano Picón.

\section{References}

Alonso, J., \& Román, J. M. (2005). Prácticas educativas familiares y autoestima [Educational practices in the family and self-esteem]. Psicothema, 17(1), 76-82. 
Retrieved from http://www.psicothema.es/ pdf/3067.pdf

Benson, J., \& Hocevar, D. (1985). The impact of item phrasing on the validity of attitude scales for elementary school children. Journal of Educational Measurement, 22, 231-240. http://doi.org/10.1111/j.1745-398 4.1985.tb01061.x

Brinthaupt, T. M., \& Erwin, L. J. (1992). Reporting about the self: Issues and implications. In T. M. Brinthaupt \& R. P. Lipka (Eds.), The self: Definitional and methodological issues (pp. 137-171). Albany, NY: State University of New York Press.

Butler, R. J., \& Gasson, S. (2005). Self Esteem/ Self Concept Scales for children and adolescents: A review. Child and Adolescent Mental Health, 10(4), 190-201. http://dx.do i.org/10.1111/j.1475-3588.2005.00368.x

Caso, N. J., Hernández-Guzmán, L., \& González-Montesinos, M. (2011). Prueba de Autoestima para Adolescentes [Selfesteem Test for Adolescents]. Universitas Psychologica, 10(2), 535-543. Recuperado de http://revistas.javeriana.edu.co/index.p hp/revPsycho/article/view/558

Coopersmith, S. (1981). Self-Esteem Inventories. Palo Alto, CA: Consulting Psychologits Press.

Davis-Kean, P. E., \& Sandler, H. M. (2001). A meta-analysis of measures of self-esteem for young children: A framework for future measures. Child Development, 72 (3), 887-906. http://dx.doi.org/10.1111/1467-8 624.00322

De Tejada, M. (2009). Factores socioculturales y competencia para la lectura de textos narrativos en escolares [Sociocultural factors and narrative reading skills in schoolage children] (Unpublished doctoral dissertation). Universidad Central de Venezuela, Caracas.

De Tejada, M. (2015). Escala para Evaluación de la Autoestima en escolares venezolanos. Una propuesta para su medición [Scale to evaluate self-esteem in school Venezuelan school-age children. A proposal for measurement]. Trabajo de ascenso a la categoría titular, Instituto Pedagógico de Caracas, Universidad Pedagógica Experimental Libertador.

Giménez, C., Cortés, M., \& Loaeza, P. (2003). Confiabilidad y validación con niños mexicanos de dos instrumentos que miden la autoestima [Reliability and validation with Mexican children of two instruments that measure self-esteem]. Salud Mental, 26(4), 40-46. Recuperado de http://www.medigraphic.com/pdfs/salme n/sam-2003/sam034e.pdf

Hair, J., Anderson, R., Tathan, R., \& Black, W. (2005). Análisis multivariante [Multivariate analysis]. Madrid: Prentice Hall.

Harter, S. (1985). The Self-Perception Profile for Children: Revision of the Perceived Competence Scale for Children. Denver, CO: University of Denver.

Harter, S., \& Pike, R. (1984). The Pictorial Scale of Perceived Competence and Social Acceptance for Young Children. Child Development, 55, 1969-1986. http://dx.doi. org/10.2307/1129772

Marsh, H. W. (1986). Negative item bias in ratings scales for preadolescent children: A cognitive-developmental phenomenon. Developmental Psychology, 22, 37-49. http:// dx.doi.org/10.1037/0012-1649.22.1.37

Marsh, H. W. (1988). SDQ I Manual E) Research Monograph: Self-Description Questionnaire. San Antonio, TX: Psychological Corporation.

Mérida, R., Serrano, A., \& Tabernero, C. (2015). Diseño y validación de un cuestionario para la evaluación de la autoestima en la infancia [Design and validation of a questionnaire for self-esteem in infancy]. Revista de Investigación Educativa, 33(1), 149-162. http://dx.doi.org/10.6018/rie.33.1 .182391

Muñiz, J., Elosua, P., \& Hambleton, R. K. (2013). Directrices para la traducción y adaptación de los tests: segunda edición [International Test Commission Guidelines for test translation and adaptation: Second edition]. Psicothema, 25(2), 151-157. http:/ /dx.doi.org/10.7334/psicothema2013.24 
Navarro, E., Meléndez, J., Sales, A., \& Sancerni, M. (2012). Desarrollo infantil y adolescente: trastornos mentales más frecuentes en función de la edad y el género [Child and adolescent development: Common mental disorders according to age and gender]. Psicothema, 24(3), 377-383. Retrieved from http://www.psicothema.co $\mathrm{m} / \mathrm{PDF} / 4026 . \mathrm{pdf}$

León, C. (2007). Secuencias del desarrollo infantil integral [Sequences of integral child development]. Caracas: UCAB.

Muñoz, L. (2011). Autoestima, factor clave en el éxito escolar: relación entre autoestima y variables personales vinculadas a la escuela en estudiantes de nivel socio-económico bajo [Self-esteem, key factor in school success. Relation between self-esteem and personal variables related to school in students of low socioeconomic level] (Unpublished master's thesis). Universidad de Chile, Santiago.

Palacios, J. (2000). Desarrollo del yo [Development of the Self]. En F. López, I. Etxebarría, M. J. Fuentes \& M. J. Ortiz (Coords.), Desarrollo afectivo y social (pp. 231-245). Madrid: Pirámide.

Piers, E. V. (1969). Manual for the Piers-Harris Children's Self-Concept Scale. Nashvile, TN: Counselor Recordings and Tests.

Piers, E. V. (1984). Piers-Harris Children's SelfConcept Scale: Revised Manual. Los Angeles, CA: Western Psychological Services.

Piers, E. V., Harris, D. B., \& Herzberg, D. S. (2002). The Piers-Harris Children's Self Concept Scale (2th. ed.). Los Angeles, CA: Western Psychological Services.

Ramírez, P., Duarte, J., \& Muñoz, R. (2005). Autoestima y refuerzo en estudiantes de $5 .^{\mathrm{o}}$ básico de una escuela de alto riesgo [Selfesteem and reinforcement in 5th grade students of a school of high risk]. Anales de Psicología, 21(1), 102-115. Recuperado de http://www.um.es/analesps/v21/v21_1/1 2-21_1.pdf

Ramos, R., \& Santamaría, P. (2010). Cuestionario de evaluación multimedia y multilingüe de la autoestima [Multilingual and Multimedia qüestionnaire for evaluating self-esteem]. Madrid: TEA ediciones.

Rodríguez, A. (2012). Efectos de un programa de inteligencia emocional en la autoestima de niños y niñas de educación primaria [Effects of a program of emotional intelligence on primary school children's self-esteem] (Unpublished masters' thesis). Universidad Rafael Urdaneta, Maracaibo.

Rosenberg, M. (1965). Society and the adolescent self-image. Princeton, NJ: Princeton University Press.

Schmitt, D. P., \& Allik, J. (2005). Simultaneous administration of the Rosenberg SelfEsteem Scale in 53 nations: Exploring the universal and culture-specific features of global self-esteem. Journal of Personality and Social Psychology, 89(4), 623-642. http://dx .doi.org/10.1037/0022-3514.89.4.623

Serrano, A., Mérida, R., \& Tabernero, C. (2016). La autoestima infantil, la edad, el sexo y el nivel socioeconómico como predictores del rendimiento académico [Children's self-esteem, age, sex, and socioeconomic level as predictors of academic performance]. Revista de Investigación en Educación, 14(1), 33-66. Recuperado de http://reined.webs.uvigo.es/ ojs/index.php/reined/article/view/1139/375

Twenge, J. M., \& Campbell, W. K. (2002). Self-Esteem and socioeconomic status: A meta-analytic review. Personality and Social Psychology Review, 6(1), 59-71. http://dx.do i.org/10.1207/S15327957PSPR0601_3

Verduzco, M., Gómez, E., \& Durán, C. (2004). Influencia de la autoestima en la percepción del estrés y el afrontamiento en niños en edad escolar [Influence of self-esteem in the perception of stress and coping in school-age children]. Salud Mental, 27(4), 18-25. Recuperado de http://new.medigraphic.com/cgi-bin/res umen.cgi?IDARTICULO = 16471

Villarroel, V. (2001). Relación entre autoconcepto y rendimiento académico [Relation between self-concept and academic performance]. Psykhe: Revista de la Escuela de Psicología, 10(1), 3-18. 
Recuperado de http://www.psykhe.cl/index .php/psykhe/article/view/418/398

\section{Notes}

* $\quad$ Research article. 